\title{
TNK1 Gene
}

National Cancer Institute

\section{Source}

National Cancer Institute. TNK1 Gene. NCI Thesaurus. Code C24875.

This gene plays a role in signal transduction and the negative regulation of cell growth. 